\title{
Economic feasibility of CHP facilities fueled by biomass from unused agriculture land: Case of Croatia
}

\author{
Antun Pfeifer ${ }^{a}$, Dominik Franjo Dominković ${ }^{b}$, Boris Ćosić ${ }^{c, *}$, Neven Duić ${ }^{d}$ \\ a International Centre for Sustainable Development of Energy, Water and Environment Systems - SDEWES Centre, Zagreb, Croatia \\ ${ }^{\mathrm{b}}$ Technical University of Denmark, Department of Energy Conversion and Storage, Frederiksborgvej 399, DK-4000 Roskilde, Denmark \\ ${ }^{\mathrm{c}}$ Adria Section of the Combustion Institute, Zagreb, Croatia \\ ${ }^{\mathrm{d}}$ University of Zagreb, Faculty of Mechanical Engineering and Naval Architecture, Zagreb, Croatia
}

\section{A R T I C L E I N F O}

\section{Article history:}

Received 17 November 2015

Received in revised form 21 April 2016

Accepted 24 April 2016

Available online 2 May 2016

\section{Keywords:}

Biomass

Energy planning

Combined heat and power

Short rotation coppice

Techno-economic analysis

Unused agricultural land

Renewable energy sources

\begin{abstract}
A B S T R A C T
In this paper, the energy potential of biomass from growing short rotation coppice on unused agricultural land in the Republic of Croatia is used to investigate the feasibility of Combined Heat and Power (CHP) facilities fueled by such biomass. Large areas of agricultural land that remain unused for food crops, represent significant potential for growing biomass that could be used for energy. This biomass could be used to supply power plants of up to $15 \mathrm{MW}_{\mathrm{e}}$ in accordance with heat demands of the chosen locations. The methodology for regional energy potential assessment was elaborated in previous work and is now used to investigate the conditions in which such energy facilities could be feasible. The overall potential of biomass from short rotation coppice cultivated on unused agricultural land in the scenarios with $30 \%$ of the area is up to $10 \mathrm{PJ} / \mathrm{year}$. The added value of fruit trees pruning biomass represents an incentive for the development of fruit production on such agricultural land. Sensitivity analysis was conducted for several parameters: cost of biomass, investment costs in CHP systems and combined change in biomass and technology cost.
\end{abstract}

(c) 2016 Elsevier Ltd. All rights reserved.

\section{Introduction}

In the European Union's (EU) struggle to achieve the energy package goals in 2020, in particular increasing the share of the EU energy consumption produced from renewable resources to $20 \%$, biomass has a very significant position with $68 \%$ share of total gross inland consumption of renewable energy in 2011 and $8.4 \%$ of total final energy consumption in Europe in 2011. At the same time biomass is almost exclusive renewable fuel for heat with $95.5 \%$ share [1]. In Croatia, besides being widely used for domestic heating in rural areas, biomass is a dominant renewable resource in the most recent National Renewable Energy Action Plan, with a planned contribution of $26 \mathrm{PJ}$ and $85 \mathrm{MW}$ of capacity in 2020 [2]. These ambitious goals rest on biomass due to its socio-economic potential in Croatia, which is higher compared to the other renewable resources because of Croatia's forest and land potential. Croatia has problems with unemployment, similarly to some other countries in the EU, and at the same time large areas of unused agricultural land, both in public and private sectors. Extensive

\footnotetext{
* Corresponding author at: Ivana Lučića 5, 10000 Zagreb, Croatia.

E-mail addresses: antun@sdewes.org (A. Pfeifer), dodo@dtu.dk (D.F. Dominković), Boris.Cosic@fsb.hr (B. Ćosić), Neven.Duic@fsb.hr (N. Duić).
}

research has been conducted so far on the marginal land use for growing crops for biomass and biofuels [3]. Today, overall agricultural land in Croatia amounts to 2,955,728 ha. Out of that, $1,074,159$ ha is considered suitable, $1,074,510$ ha is considered to be of limited suitability and 806,328 ha is listed as unsuitable for agricultural production [4]. In order to fulfil its goals regarding renewable energy sources integration, while making a change and progress in other mentioned fields, Croatia might resort to Short Rotation Coppice (SRC), a form of cellulose biomass that has already been developed for energy use in some other countries of the EU. Previous research in this field in EU countries focused on annual yields [5] and most favorable species [6], and impact on soil [7] and biodiversity [8]. These energy crops are eligible for cultivation on a wide range of soils that are of limited suitability or unsuitable for agricultural production. Initial studies have already been carried out in the field of choosing the optimal clones of willow and poplar. These species are common in Croatia and thus most relevant candidates for use on larger scale, as shown for white willow [9], with respect to the issue of marginal land [10] and to the way appropriate clones of willow are chosen [11]. Moreover, initial research has been carried out to frame the overall potential of marginal land on the whole territory of Croatia [12]. Although there are some experimental fields of willow being 
studied, there is no commercial SRC farm currently in Croatia. Recent study discussed the uptake of the SRC by the farmers in Europe [13], which demonstrated that the potential profitability of SRC is not yet recognized, while the study of economics of SRC in continental Europe gives the roadmap toward the increase in feasibility compared to other types of crops [14].

The usage of SRC, as well as other energy crops started in Scandinavian countries right after the oil crisis in the 1970s. Production chains with energy crops are well developed in Sweden, Finland, the UK and Denmark and are making progress in countries of Central and South Europe. Recent data on areas under various energy crops is given in Table 1.

Important part of energy transition toward systems based on renewable energy sources is district heating with combined heat and power (CHP) plants using biomass as the energy source. Because of their importance, a lot of research has been conducted recently to investigate the application of these types of solutions. In [15] results for three variants of combined heat and power (CHP) biomass plants were calculated. Kilkis [16] developed a model for the net-zero exergy district development for a city in Sweden, which among other units includes a CHP plant with district heating and cooling system. Krajačić et al. [17] provided an overview of potential feed-in tariffs for different energy storage technologies. Wang et al. [18] published a paper dealing with multi-objective optimization of a combined cooling, heating and power system driven by solar energy. Raine et al. [19] optimized combined heat and power production for buildings using heat storage. Mikulandrić et al. [20] examined the possibilities of a hybrid District Heating (DH) systems in small towns, with advantages in lower cost when the system is powered by renewable energy. Recently, the study of biomass CHP and DH applications in the urban areas being competitive with natural gas was conducted in Pantaleo et al. [21], with detailed sensitivity analysis conducted in a separate paper [22]. In Rudra et al. [23], the research goes further to propose more complex novel polygeneration systems based on biomass utilization, which increases the efficiency of resource utilization, minimizes the impact on the environment due to distributed generation and, through flexible operation, supports the integration of renewable energy [23]. Research in the use of biomass for CHP systems is well connected to the overall goal to achieve energy systems with $100 \%$ energy produced from the renewable sources. In the recent research regarding the possibility of $100 \%$ renewable energy system in the whole SEE, biomass is viewed more conservatively than before, with the energy potential of $726 \mathrm{PJ} /$ year for the entire region. The use of SRC could increase this potential further [24].

In this paper, the research builds upon the current state-of-theart scientific work by showing how unused agriculture land in Croatia could be used to cultivate SRC, which later could be used as fuel in the CHP plants. This is considered firstly for a novel system that combines cooling, heating and power and is supplied by storage. Further elaboration is conducted regarding feasibility of such system and the sensitivity analysis of the most important factors.

\section{Metodology}

Short rotation coppice species are perennial species which have a lifetime of 15-20 years, depending on the species, and are usually harvested every 2-8 years. In order to have continuous output of biomass for energy plants each hectare of agricultural land deemed to be at the disposal is divided into three fields, with the assumption that in every rotation only one field would be harvested, so that one hectare supplies biomass continuously during the lifetime
Table 1

Cellulosic energy crops in EU in 2011 [1].

\begin{tabular}{llll}
\hline & Willow (ha) & Poplar (ha) & Miscanthus (ha) \\
\hline AT & $220-1100$ & $880-1100$ & 800 \\
BE & 60 & & 120 \\
DK & 5697 & 2807 & 64 \\
FR & 2300 & & $2000-3000$ \\
DE & 4000 & 5000 & 2000 \\
IE & 930 & 5490 & 2200 \\
IT & 670 & & $50-100$ \\
LT & 550 & 300 & \\
PL & $5000-9000$ & 550 & \\
SE & 11,000 & & 450 \\
UK & $1500-2300$ & & $10,000-11,000$ \\
\hline
\end{tabular}

of the species [25]. Therefore, the technical potential of the respective county or region is calculated in Eq. (1):

$\sum_{i=1}^{n} B_{t e h}(i)=\sum_{i=1}^{n}\left(A(i) * P_{y}(i) * k+A_{f}(i) * P_{f}(i)\right)$

where $B_{t e h}(i)$ is the technical potential of the county $(i)(t), A(i)$ is the area of unused agricultural land at the disposal (ha), $P_{y}(i)$ is the yearly production of biomass from the species used on the area $A$ in (t/year) and $k$ is the factor of rotation which determines the pace of harvesting. For every species or clones, factor $k$ can be arbitrated according to the location in question. Furthermore, $A_{f}(i)$ is the area of the county $(i)$ under fruit trees (ha) and $P_{f}(i)$ is the yearly production of biomass from pruning of the fruit trees ( $t / y e a r)$.

The energy potential of the respective county or region is calculated with the assumption that the obtained biomass is stored after harvesting and finally reaches the gate of energy plant with moisture value of $30 \%$ and lower heating value of $3.5 \mathrm{~kW} \mathrm{~h} / \mathrm{kg}$ respectively [26]. The energy potential is calculated in Eq. (2):

$B_{\text {ep }(i)}=B_{\text {teh }(i, S R C)} * H d_{S R C}+B_{\text {teh }(i . f r u i t)} * H d_{\text {fruit }}$

where $B_{e p(i)}$ is the energy potential (GJ/year) of the county (i) and $H d_{S R C}$ is the lower heating value of the biomass from SRC at the gate of energy plant $(\mathrm{GJ} / \mathrm{t})$, while $B_{\text {teh(ifruit })}$ is the technical potential of biomass from fruit trees pruning ( $\mathrm{t} /$ year), $B_{\text {teh }(i, S R C)}$ is the technical potential of biomass from SRC (t/year) and $H d_{\text {fruit }}$ is the average lower heating value of biomass from fruit trees pruning $(G J / t)$.

For the calculation of the price of biomass at the gate of power plant, the method from [27] was used in Eq. (3). The price of biomass as a function of the SRC farm distance from the power plant is calculated:

$C_{\mathrm{B}, \mathrm{E}}=\sum_{i=1}^{n} \frac{\left[C_{B}+\left(T_{p} \times U_{i}\right)\right] \times K_{B i}}{P_{B}}$

where $C_{\mathrm{B}, \mathrm{E}}$ is the price of biomass at the gate of power plant $(€ / \mathrm{t}), C_{\mathrm{B}}$ is the price of biomass harvested from the SRC farm $(€ / t), T_{p}$ is the specific cost of transport $(€ / \mathrm{t} / \mathrm{km}), U_{i}$ is the average distance between the farm and power plant $(\mathrm{km}), K_{B i}$ is the amount of biomass from the location $(i)(\mathrm{t}), P_{B}$ is the total yearly amount of biomass used by the power plant $(\mathrm{t})$.

For the purpose of gaining a better insight into regional differences in potential, which is crucial for economic viable choice of location for both SRC farms and biomass power plants, the scenario approach has been adopted. Various percentages of unused agricultural areas have been taken into account and the difference between public and private agricultural land has been considered in order to benefit the future research of different operational and maintenance costs of SRC farms. The farms can be run by hired workforce and mechanisation compared to private landowners that can use their own, slightly modified mechanisation and labor, which might lower the costs significantly. 
The cost of the biomass harvested from the SRC farm is calculated according to Eq. (4) $[12,25]$ :

$C_{B}=T_{S}+T_{Z}+T_{O \& M}$

where $T_{S}$ is the cost of seeding material ( $\left.€ / \mathrm{ha}\right), T_{Z}$ is the cost of land cultivation and $T_{O \& M}$ is the cost of labor and harvesting in the life cycle of species. Typical costs in Europe are shown in Table 2. The selling price is expressed in Euro per ton of dry matter (DM).

In each scenario, a combination of SRC, predominantly willow and fruit cultures, will be considered for the production of biomass. For the calculation of biomass costs at the respective power plants' gate and the Net Present Value (NPV) for each location, a code programmed in MATLAB has been used. It is an original code from [25], altered in order to take into account unused agricultural land instead of forests and forest residue. The model develops a network of quadrants with each quadrant representing an area of $1 \mathrm{~km}^{2}$. The model calculates the average price per tonne of biomass $\left(C_{B}\right.$, $\mathrm{E}$ ) in each quadrant, and selects the most appropriate site. The code firstly positions in a particular quadrant and then calculates the amount of biomass resources which are sorted according to the distance. Biomass being closer has an advantage over the more distant biomass until it reaches the last source of biomass to be taken. For the most favorable location it lists the correct order of the sources, which it takes the biomass from with the amount of biomass taken from each source. Due to the simple assignment of input data, a piece of code that selects the waste biomass from wood processing industry can be easily modified if there is another potential source of biomass, such as agricultural land planted with SRC. All locations are given in the form of geographical coordinates: latitude and longitude. Distances between specific coordinates of the model are calculated using the Haversine formula, which takes the Earth as a sphere, ignoring the effects of the ellipse.

The Haversine formula has been first used in the beginning of the 19th century. The formula calculates the distances between the two points on a sphere using the spherical triangles. Thus, simplifying the Earth's shape as a sphere instead of an ellipsoid, the Haversine formula can be used. Due to the relatively short distances between different areas in the model, this simplification doesn't influence the result significantly since the mistake never goes beyond $0.5 \%$ [28].

\section{Case study Croatia}

Macro-locations for power plants have been chosen according to local heat demands obtained from the Sustainable Energy Action Plans (SEAP) of the cities considered. In each location that was considered, heat demand was taken from the SEAP and used as a base for calculation of the required CHP installed capacity, which was $15 \mathrm{MW}_{\mathrm{e}}$ and $30 \mathrm{MW}_{\mathrm{t}}$ for each location being investigated.

Since there are no commercial SRC farms in Croatia so far, the price of biomass from such a farm was calculated including the establishment of the farm, yearly expenses for workforce and mechanisation and yearly production of biomass from the hectare of area, taking into consideration various soil quality and suitability. Investment, operation and maintenance costs were estimated to be $6267 € /$ ha for the whole life cycle of 12 years of willow cultivation, achieving $12 t_{D M} /$ ha/year or $144 t_{D M} /$ ha in the life cycle of the SRC farm. Therefore, $C_{\mathrm{B}}$ of biomass from such a farm was estimated to be $43.47 € / t$ [12]. In the case of willow, a 3-year rotation has been selected for the calculation. Using state owned land (through land concession or other instruments) is beneficial from the point of view of ownership, which is often a great barrier for any area intensive project in Croatia, since private land is often shared by multiple owners. On the other hand, at locations where
Table 2

Typical costs for SRC farms [12,30].

\begin{tabular}{lllll}
\hline Location & Species & $\begin{array}{l}\text { Cultivation } \\
\text { costs }(€ / \text { ha })\end{array}$ & $\begin{array}{l}\text { Operation } \\
\text { costs }(€ / \mathrm{ha} / \mathrm{y})\end{array}$ & $\begin{array}{l}\text { Selling } \\
\text { price } \\
\left(€ / \mathrm{t}_{\mathrm{DM}}\right)\end{array}$ \\
\hline Sweden - Nynas Gard & Willow & 1222 & 330 & 65 \\
Sweden - Puckgarden & Willow & 1110 & 265 & 52 \\
Latvia & Willow & 1450 & $\mathrm{n} / \mathrm{a}$ & $\mathrm{n} / \mathrm{a}$ \\
Latvia - Salixenergi & Willow & 1630 & 480 & $\mathrm{n} / \mathrm{a}$ \\
France- Bretagne & Willow & 2545 & 355 & $\mathrm{n} / \mathrm{a}$ \\
Germany - Goettingen & Poplar & 2750 & 250 & 65 \\
Italy - Rinnova & Poplar & 2320 & 875 & 55 \\
Croatia & Willow & 3916 & 196 & 43.47 \\
\hline
\end{tabular}

private land could be utilized without a very costly and time consuming process of dealing with ownership problems, the costs of land and mechanisation could be lower, presenting the investors with the opportunity to reach the scenarios presented in sensitivity analysis, making the SRC production feasible.

In order to make comparison, as well as to preserve biodiversity and encourage production in the region, biomass from fruit trees pruning was also taken into account in the scenarios. The amount of biomass from fruit trees was calculated according to [29]. Table 3 reports on how much biomass could be obtained by pruning of plantations of respective fruit cultures. The combustion of other types of biomass with biomass from SRC is considered desirable at this stage in the practice of Central European countries [30].

The separate issue is the statistical coverage of unused agricultural land. It has been followed through yearbooks of the National Bureau of Statistics until the year 2005, when due to the adjustment to the European standards in statistics, unused land was no longer published as a dataset. In the year 2009, a new Agency for Agricultural Land was founded and started to review data on state-owned agricultural land.

Their newest findings were used here to calculate available agricultural land in each county. For private unused agricultural land, data from the Statistical Yearbook 2004 of the National Bureau of Statistics was used. Although the difference of 10 years in datasets could cause some inaccuracies, assumptions in the scenarios were conservative enough to make sure that the calculated technical potential could be actually achieved [31]. In Table 4 the data on unused agricultural land is provided [32].

Private land stands for exclusively private-owned land, while the state-owned land is in the ownership of local selfgovernment or the companies such as the Croatian Forests, owned directly by the country of Croatia. The difference is significant due to the state of the land, concerning the ownership by private citizens, which usually makes the land on the same location more fragmented and causes significant practical difficulties for anyone trying to put the land into use.

For the case study of Croatia, scenarios were devised as follows:

SCENARIO $1-30 \%$ of unused agricultural land was used to cultivate willow SRC. The scenario was divided according to the ownership to show the difference in local potential when:

(1a) $30 \%$ of state-owned land was used

(1b) $30 \%$ of private land was used

(1c) $30 \%$ of aggregated state-owned and private land was used

SCENARIO 2 - 20\% of unused agricultural land was used to cultivate willow SRC. The scenario was divided according to the ownership to show the difference in local potential when:

(2a) $20 \%$ of state-owned land was used

(2b) $20 \%$ of private land was used

(2c) $20 \%$ of aggregated state-owned and private land was used 
Table 3

Biomass from fruit trees pruning [29].

\begin{tabular}{lc}
\hline & Total biomass $(\mathrm{kg} / \mathrm{ha})$ \\
\hline Fruit trees & \\
Apple & 5571.43 \\
Pear & 5833.33 \\
Peach and nectarine & 2921.21 \\
Apricot & 1619.58 \\
Cherry (sweet and sour) & 1783.07 \\
Plum & 2053.15 \\
Fig & 1281.12 \\
Dry fruit trees & \\
Walnut & 538.04 \\
Hazelnut & 1848.48 \\
Almond & 1625.17 \\
Grape & \\
Total & 4258.37 \\
Olive & \\
Total & 2522.22 \\
\hline
\end{tabular}

Table 4

Unused agricultural land divided according to ownership [25,32].

\begin{tabular}{lrc}
\hline County & Public (ha) & Private (ha) \\
\hline Krapina-Zagorje & 115.27 & 1783 \\
Varazdin & 1009.79 & 1469 \\
Medjimurje & 1702.89 & 2910 \\
Koprivnica-Križevci & 2563.36 & 987 \\
Osijek-Baranja & 3826.71 & 5316 \\
Vukovar-Srijem & 4445.69 & 2662 \\
Virovitica-Podravina & 7019.16 & 5221 \\
Zagreb & 7989.94 & 8890 \\
Bjelovar-Bilogora & 9974.94 & 15,476 \\
Požega-Slavonia & $15,391.35$ & 12,875 \\
Brod-Posavina & $19,689.77$ & 7326 \\
Karlovac & $32,767.84$ & 82,259 \\
Sisak-Moslavina & $33,733.16$ & 57,412 \\
\hline
\end{tabular}

SCENARIO 3 - 10\% of unused agricultural land was used to cultivate willow SRC. The scenario was divided according to the ownership to show the difference in local potential when:

(3a) $10 \%$ of state-owned land was used

(3b) $10 \%$ of private land was used

(3c) $10 \%$ of aggregated state-owned and private land was used

SCENARIO 4 - $20 \%$ of unused agricultural land was used to combine cultivation of willow SRC with the increase in production of the most widespread fruit sorts in Croatia (apple, pear, peach, cherry, plum, walnut and hazelnut) according to the data from [33]. The scenario was divided according to the ownership to show the difference in local potential when:

(4a) $20 \%$ of aggregated state-owned and private land was used, divided to achieve a $100 \%$ increase in areas under most widespread fruit sorts and to use the rest of the area for SRC cultivation.

(4b) Same as in 4a, but with a goal to achieve a $50 \%$ increase in areas under fruit sorts.

(4c) Same as in $4 \mathrm{~b}$, but with a goal to achieve a $25 \%$ increase in areas under fruit sorts.

District heating systems powered by the acquired biomass ran on novel Combined Heat and Power (CHP) plant, in order to meet as much energy demand as possible. For this case study, data from Table 4 was calculated as the base data of the CHP plant. The District Heating System (DHS) includes heating grid and heat storage to allow the plant to extend its availability during months with lower heat demand and to enable peak shaving.

Recently, following the European Commission's recommendation, a new form of subsidizing the investment in renewable energy sources has been implemented in Croatia. Instead of feedin tariffs used before, a feed-in premium has been approved to be the main scheme for subsidizing renewables [34]. It is expected that a tender will be called for filling in the quotas set for specific technology in which the offer with the lowest feed-in premium will be chosen. However, as the procedure is only in the starting phase, the range of offers that will be offered is still unclear. Thus, the best approximation can be found in Dominković et al. [35]. The calculated feed-in premium should be around $0.085 € / \mathrm{kW}$ h of electricity supplied to the grid in order that subsidy level remains in the same range as it was the case with feed-in tariffs. For this case study, the level of subsidy is given in Table 5.

In Fig. 1, the simulated behavior of the CHP plant on the market is given. The blue ${ }^{1}$ line is the income from the market, according to the Nordpool market prices from 2014, and the red line is the income including the Feed-in Premium.

Since the new Act is not yet in force and no ordinances have been declared to describe how the feed-in premium will be implemented, the sensitivity analysis is conducted under the Act that is still in force and uses a feed-in tariff, calculated on the basis of the average, "blue" tariff from [36].

\section{Results}

In this section, the results of the methodology applied in the case study of Croatia are presented. Also, the sensitivity analysis is performed at the end of the chapter to discuss the circumstances in which the exploitation of this potential for fuel in CHP could be feasible.

Technical potential and energy potential of biomass from SRC for the scenarios $1 \mathrm{a}, 1 \mathrm{~b}, 2 \mathrm{a}, 2 \mathrm{~b}, 3 \mathrm{a}$ and $3 \mathrm{~b}$ for six most promising counties are shown in Fig. 2.

There is a noticeable potential in the Karlovac and SisakMoslavina counties due to the large areas of unused agricultural land in those counties. This can be seen in even greater disparity in Fig. 3, which shows the results of technical and energy potential of biomass from SRC for the scenarios $1 c, 2 c$ and $3 c$.

In the scenarios $4 \mathrm{a}, 4 \mathrm{~b}$ and $4 \mathrm{c}$ shown in Fig. 4, technical and energy potential are lower due to the inclusion of the biomass from fruit trees pruning. However, the advantages of that are larger employment and the reduction of country's fruit import dependence.

Technical and energy potential for all the scenarios for the Continental Croatia (counties from Table 4), is given in Table 6. Counties of the Mediterranean Croatia were not included in this paper because of specific differences in climate and soil, which would influence the choice of SRC culture that should be cultivated. Moreover, the scarcity of agricultural land in those counties might contribute to seeing SRC as a competition with food crops. For the economic feasibility of such power plant and its DHS, the method of the Net Present Value (NPV) was used. Negative results for each of the macro-locations are presented in Fig. 5, which shows nets of $19 \times 19 \mathrm{~km}$ of each macro-location for the scenario $1 \mathrm{c}$. The values presented in Fig. 5 show that this value chain, connecting SRC and CHP with seasonal storage would not be feasible with the given parameters.

Using the code in Matlab from [35], the techno-economic analysis was conducted for macro-locations in Croatia. Results

\footnotetext{
${ }^{1}$ For interpretation of color in Fig. 1, the reader is referred to the web version of this article.
} 
Table 5

Base data for the calculation of the CHP plant [37-39].

\begin{tabular}{lll}
\hline & Amount & Unit \\
\hline Power plant availability & 0.9 & \\
Biomass price at the SRC field & 43.47 & $€ /$ ton \\
Lower calorific value (30\% moisture) & 3,500 & $\mathrm{~kW} \mathrm{~h} /$ ton \\
$\eta$ power plant total & 0.87 & \\
$\eta_{\mathrm{el}}$ & 0.29 & \\
HTP ratio & 2.00 & \\
$\eta$ storage & 0.8 & \\
Storage temperature & 90 & ${ }^{\circ} \mathrm{C}$ \\
Power plant specific investment cost & 3600 & $€ / \mathrm{kW}$ \\
Absorber investment cost & 400 & $€ / \mathrm{kW}$ \\
District system piping cost & 5820 & $€ / \mathrm{dwelling}$ \\
Dwellings connected to DHS & 8700 & \\
Storage investment cost & 56 & $€ / \mathrm{m}^{3}$ \\
Plant's own electricity consumption & $6 \%$ & \\
Discount rate & $7 \%$ & \\
Feed-in-tariff & 0.122 & $€ / \mathrm{kW}$ he \\
COP & 0.7 & \\
Design temperature for heating & 21 & ${ }^{\circ} \mathrm{C}$ \\
Design temperature for cooling & 26 & ${ }^{\circ} \mathrm{C}$ \\
Fixed power plant O\&M cost & 29 & $€ / \mathrm{kW}$ per annum \\
Variable power plant O\&M cost & 0.0039 & $€ / \mathrm{kW} \mathrm{h}$ \\
District heating O\&M cost & 75 & $€ / \mathrm{dwelling}$ per annum \\
Storage O\&M cost & 0.39 & $€ / \mathrm{m}^{3}$ per annum \\
Heating energy revenue & 0.0198 & $€ / \mathrm{kW} \mathrm{h}$ \\
Project lifetime & 14 & $\mathrm{Years}$ \\
\hline & & \\
& &
\end{tabular}

are supplied in a view of the cost of biomass at CHP plant's location - which was optimized according to this cost.

In order to supply complete information, the cost of biomass for each scenario and location is presented in Table 7. Locations in the vicinity of the Karlovac and Sisak-Moslavina counties have lower prices of biomass from SRC.

Other factors that are challenging for the implementation of SRC biomass based DHS are the size of the heating (cooling) network and the cost of SRC biomass. The cost of the biomass could be influenced in particular by encouraging private landowners to adopt SRC cultivation and use their own mechanization and workforce. In Fig. 6 the result of sensitivity analysis is presented.

The sensitivity analysis was performed for the case of Osijek macro-location because of the least amount of available land for the SRC cultivation in the surrounding counties. Furthermore, this location already has a DHS grid, which is the first criteria that would need to be fulfilled at this point, if the use of SRC is to be feasible.

The factors discussed in the analysis are investment cost, the price of biomass following investment cost changes and the price of biomass without the change of the investment cost.

Therefore, when discussing the lower price of biomass standalone, it refers to only taking into account the lower price of biomass without change of the investment cost or other conditions. When discussing the reduced investment cost, the price of biomass

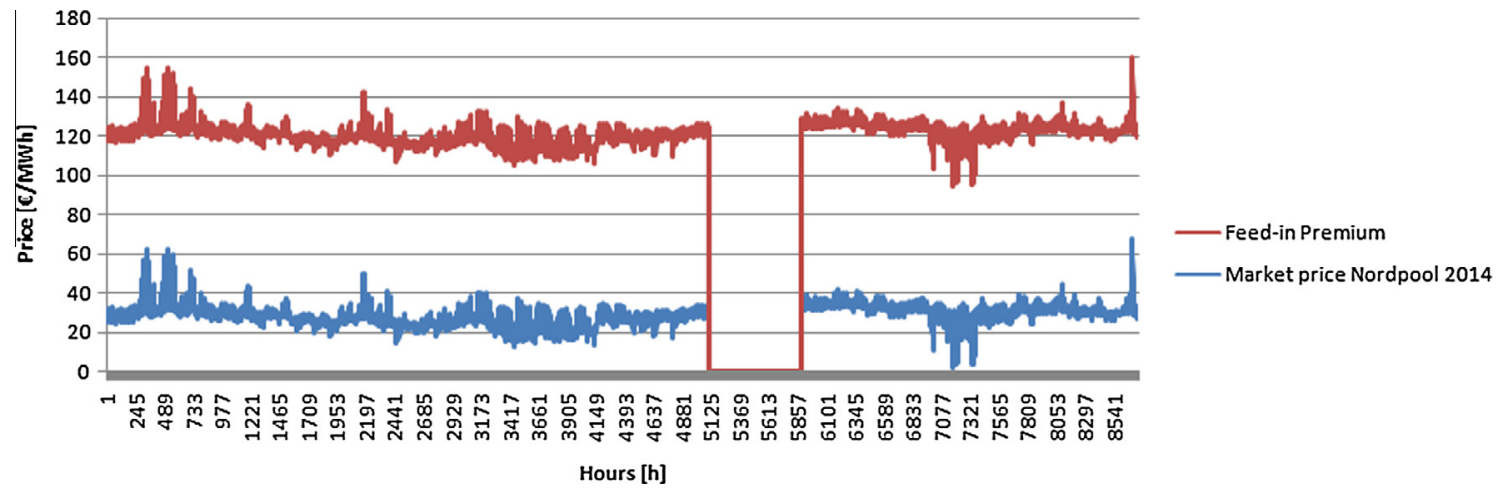

Fig. 1. Model of feed-in premium in market conditions for the CHP plant [35].

Technical potential of biomass from SRC

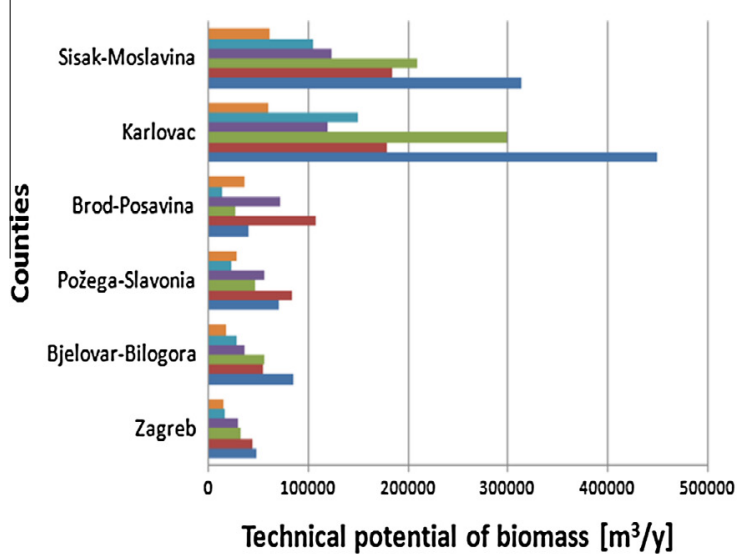

Energy potential of biomass from SRC

$\square 33 a$
$\square S 3 b$
$\square S 2 a$
$\square S 2 b$
$\square S 1 a$
$\square S 1 b$

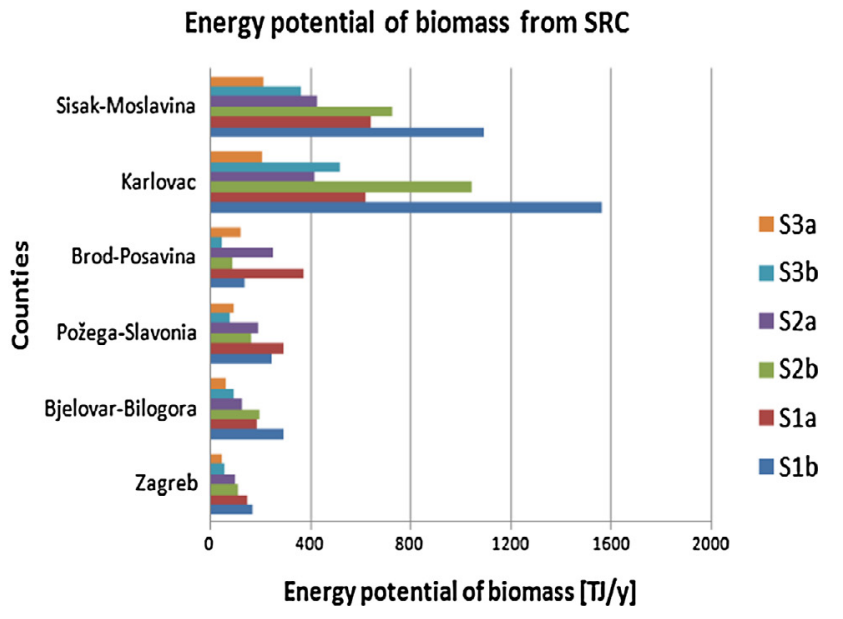

Fig. 2. Technical and energy potential of biomass from SRC in "a" and "b" scenarios. 
Technical potential of biomass from SRC

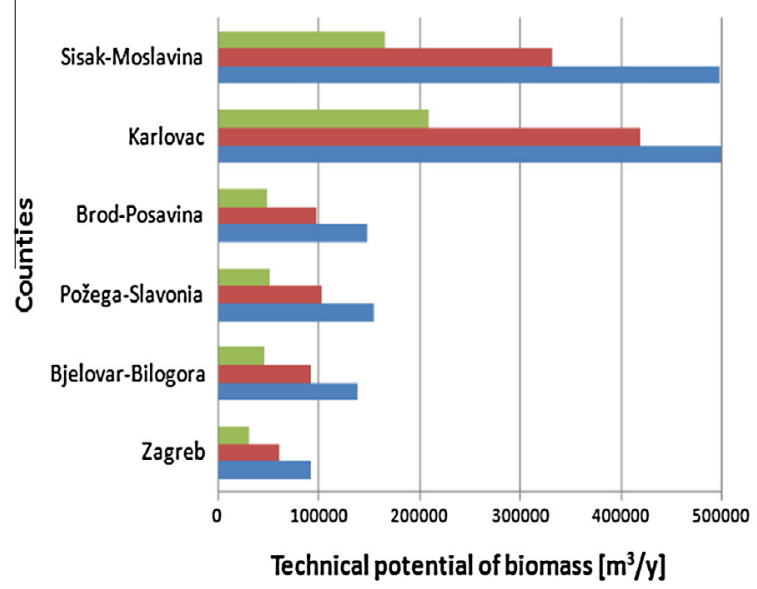

Energy potential of biomass from SRC

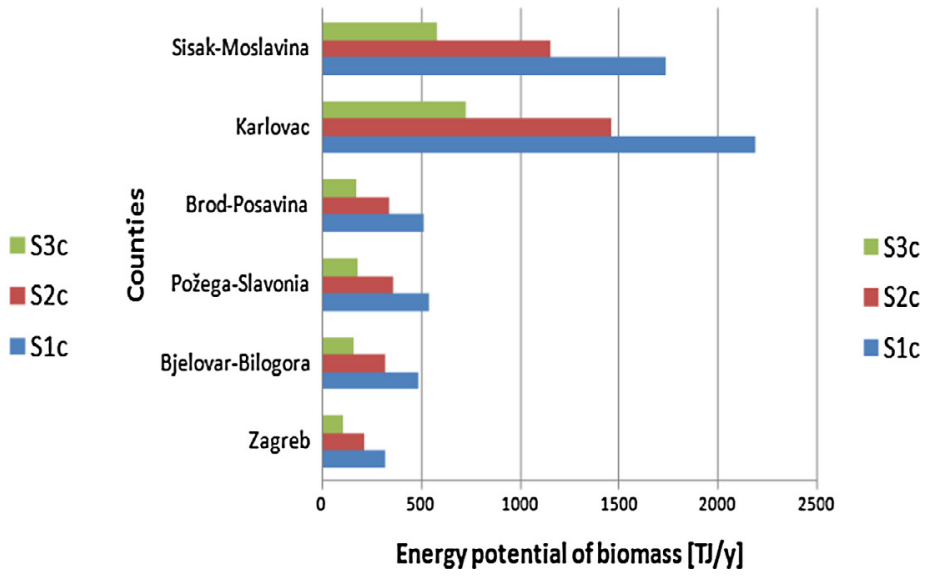

Fig. 3. Technical and energy potential of biomass from SRC in aggregate land scenarios.
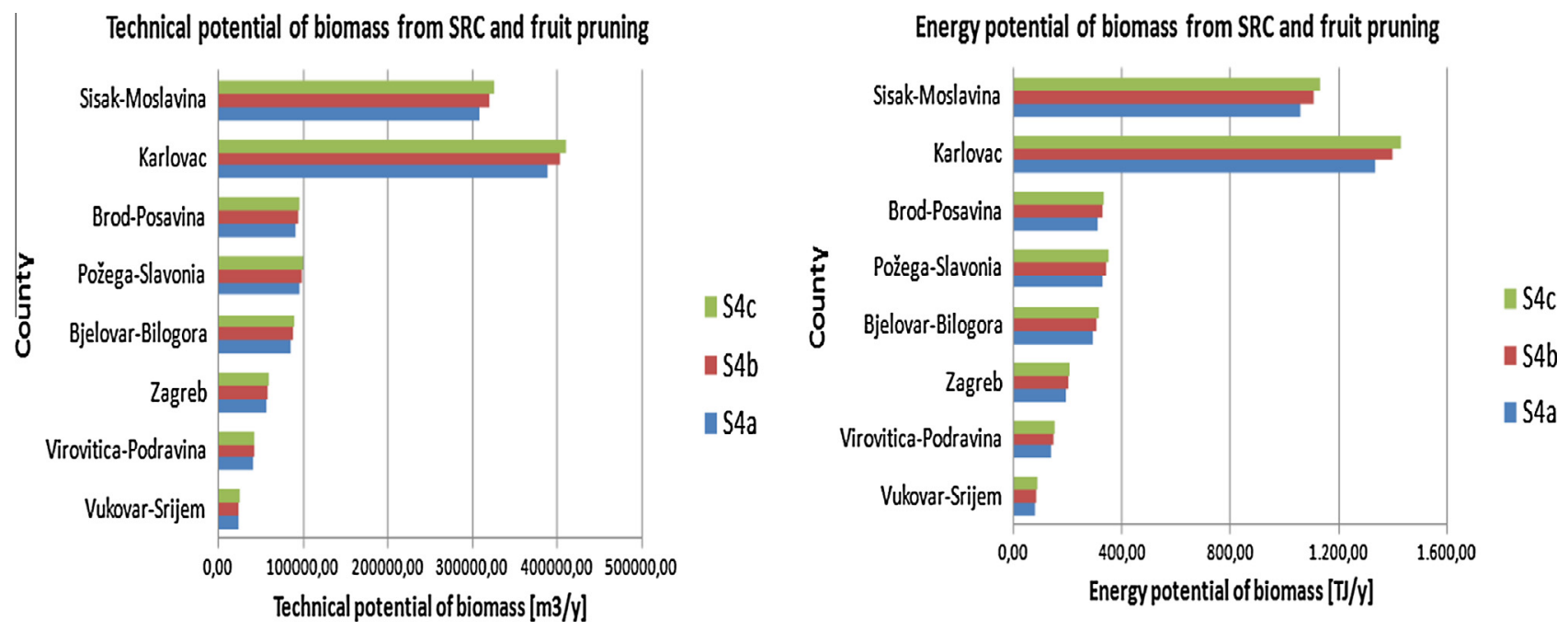

Fig. 4. Technical and energy potential of biomass from SRC and fruit trees pruning.

remains constant, while the combined approach takes into account both effects: investment cost reduction and reduction in the price of biomass at the same time.

It can be seen that only the simultaneous reductions of the investment cost and the price of biomass made the system economically feasible. Large difference toward feasibility is expected and can be reached in reality through incentives or by choosing simpler systems like the already working DH systems with the fuel shift to SRC. Price of the SRC and fruit biomass can be lower if the rate of privately owned land is increased, and the price of fruit pruning biomass decreased. The biomass price can be further lowered by using one's own labor force in a combination with entrepreneurs who own their machinery.

\section{Conclusion}

Cultivating SRC for biomass has already been commercially established value chain in some of the EU countries, especially in Sweden, Denmark, Germany, the UK, Poland and Italy. In the EU, research continues on the influence of SRC on soil, SRC yield and the best practices to exploit SRC for biomass as a valuable contribution to common energy and environmental goals in 2020 and
Table 6

Technical and energy potential for aggregated for continental Croatia.

\begin{tabular}{lll}
\hline Croatia & Technical potential $\left(\mathrm{m}^{3} / \mathrm{y}\right)$ & Energy potential $(\mathrm{TJ} / \mathrm{y})$ \\
\hline $\mathrm{S} 1_{\mathrm{a}}$ & $1,404,094$ & 4902 \\
$\mathrm{~S} 1_{\mathrm{b}}$ & $1,426,108$ & 4979 \\
$\mathrm{~S} 1_{\mathrm{c}}$ & $2,830,202$ & 9881 \\
$\mathrm{~S} 2_{\mathrm{a}}$ & 936,062 & 3268 \\
$\mathrm{~S} 2_{\mathrm{b}}$ & 950,738 & 3319 \\
$\mathrm{~S} 2_{\mathrm{c}}$ & $1,886,801$ & 6588 \\
$\mathrm{~S} 3_{\mathrm{a}}$ & 468,031 & 1634 \\
$\mathrm{~S} 3_{\mathrm{b}}$ & 475,369 & 1659 \\
$\mathrm{~S} 3_{\mathrm{c}}$ & 943,400 & 3293 \\
$\mathrm{~S} 4_{\mathrm{a}}$ & $1,169,257$ & 4176 \\
$\mathrm{~S} 4_{\mathrm{b}}$ & $1,212,193$ & 4329 \\
$\mathrm{~S} 4_{\mathrm{c}}$ & $1,233,661$ & 4356 \\
\hline
\end{tabular}

beyond. In Croatia, SRC can be seen as a new fuel, which fosters the integration of factors such as large areas of unused agricultural land, high unemployment and renewable sources inclusion goals. Analysis of regional potential shows that even conservative assumptions on the area that could be cultivated with SRC could lead to the substantial contribution to meeting local energy demands in a more sustainable way and creating new job opportunities at the same time. At the moment, the most innovative 


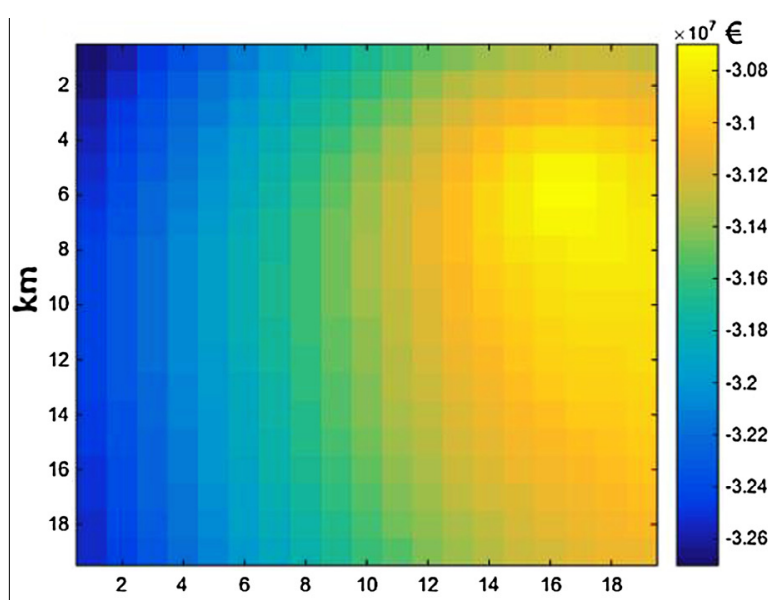

Velika Gorica (NPV $=-30698928 €$ )

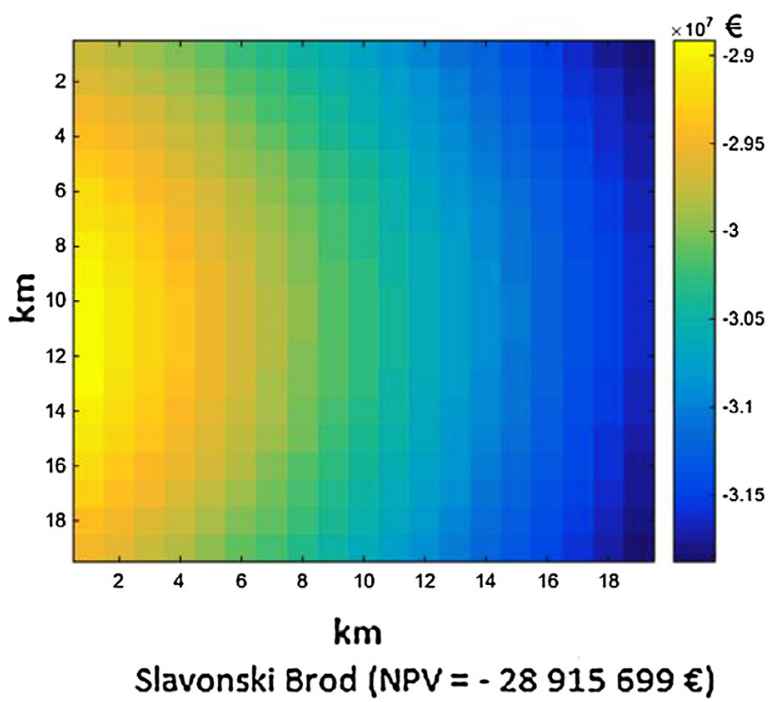

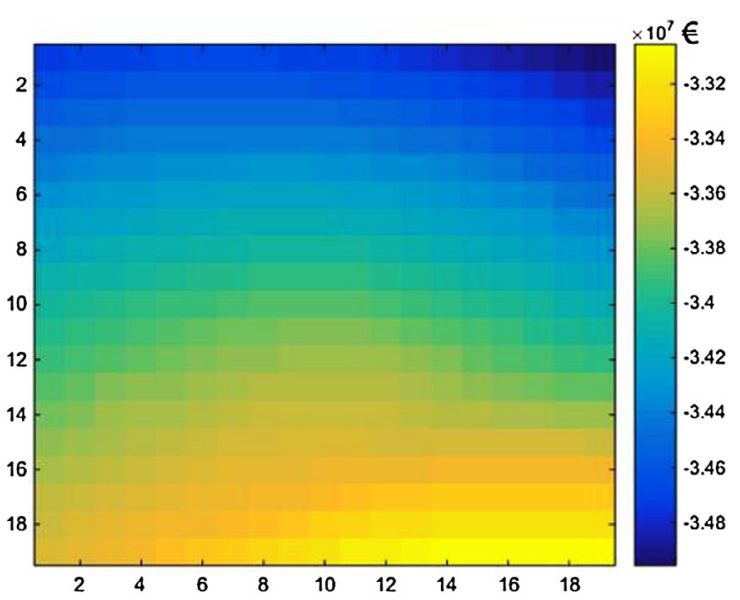

Koprivnica (NPV $=-33055331 €$ )

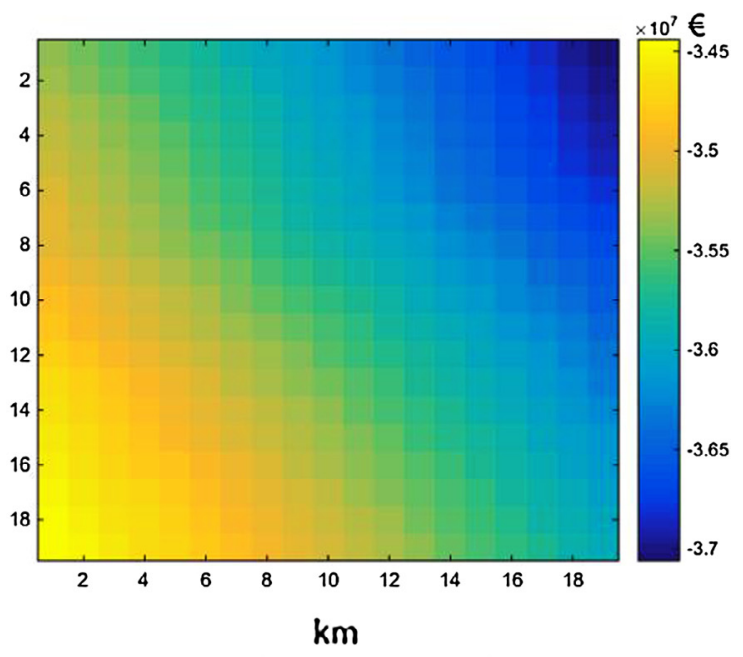

Osijek (NPV = - $34441299 \varepsilon$ )

Fig. 5. NPV of optimal locations at each macro-location for the scenario S1c.

Table 7

Cost of biomass at plant location from all scenarios.

\begin{tabular}{lllll}
\hline Location & Velika Gorica & Koprivnica & Slavonski Brod & Osijek \\
\hline Scenario & Cost $C_{\mathrm{B}, \mathrm{E}}(€ / \mathrm{t})$ & & & \\
S1a & 47.7 & 51.1 & 45.9 & 51.9 \\
S1b & 47.6 & 50.2 & 48.7 & 52.3 \\
S1c & 46.4 & 48.7 & 44.7 & 50.0 \\
S2a & 48.2 & 52.6 & 47.7 & 52.9 \\
S2b & 48.0 & 51.8 & 51.2 & 55.0 \\
S2c & 47.4 & 49.7 & 46.2 & 51.2 \\
S3a & 50.7 & 55.2 & 53.3 & 58.9 \\
S3b & 49.3 & 53.8 & 55.7 & 61.2 \\
S3c & 48.0 & 52.2 & 49.2 & 53.4 \\
S4a & 47.5 & 49.9 & 46.4 & 51.5 \\
S4b & 47.4 & 49.8 & 46.3 & 51.3 \\
S4c & 47.4 & 49.7 & 46.3 & \\
\hline
\end{tabular}

approaches with the combined heating and cooling plants with seasonal storage are not the economically feasible way of exploiting biomass from SRC, but some more conventional CHP solutions would be feasible to implement.

Further research should be conducted on more precise determination of the unused agricultural areas which could be used for the SRC cultivation. This could lead to the creation of local value chains

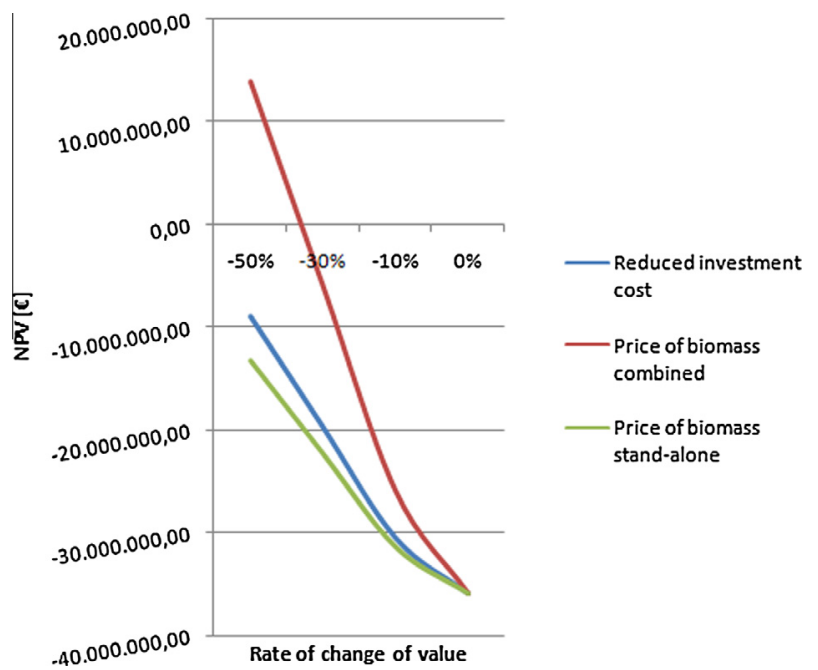

Fig. 6. Sensitivity analysis in relation to investment cost and price of biomass.

which would include SRC and other biomass sources to meet local demand in a sustainable way through DHS. Other important reductions of cost could be achieved by the use of private landowners' 
own machinery and workforce, which could make the SRC biomass more competitive and interesting for further investigation.

\section{Acknowledgement}

This work has been financially supported by the European Union's seventh Programme (FP7/2007-2013) under Grant Agreement No: 608622 (S2Biom project) and CITIES Project funded by the Danish Strategic Research Council. This support is gratefully acknowledged.

\section{References}

[1] European Bioenergy Outlook. AEBIOM; 2013.

[2] Croatian National Renewable Energy Action Plan; 2013.

[3] Lewis SM, Kelly M. Mapping the potential for biofuel production on marginal lands: differences in definitions, data and models across scales. ISPRS Int J GeoInf 2014;3:430-59.

[4] Tomic F, Kricka T, Matic S. Available agricultural areas and the use of forests for biofuel production in Croatia. Sumarski List 2008;7-8:323-30.

[5] Aylott MJ, Casella E, Tubby I, Street NR, Smith P, Taylor G. Yield and spatial supply of bioenergy poplar and willow short-rotation coppice in the UK. Journal Compilation (c) New Phytologist; 2008.

[6] Kauter D, Lewandowski I, Claupein W. Quantity and quality of harvestable biomass from populus short rotation coppice for solid fuel use-a review of the physiological basis and management influences. Biomass Bioenergy 2003;24:411-27.

[7] Baum S, Weih M, Busch G, Kroiher F, Bolte A. The impact of short rotation coppice plantations on phytodiversity. Landbauforschung - vTI Agric Forest Res 2009;3(59):163-70.

[8] Hofmann-Schielle C, Jug A, Makeschin F, Rehfuess KE. Short-rotation plantations of balsam poplars, aspen and willows on former arable land in the Federal Republic of Germany. I. Site-growth relationships. For Ecol Manage 1999; $121: 41-55$.

[9] Kajba D, Bogdan S, Katičić-Trupčević I. White willow biomass production in a short rotation clonal test in Croatia. Šumarski List 2004:9-10:509-15. Zagreb.

[10] Bogdan S, Kajba D, Katičić I. Production of biomass in clonal tests of arborescent willow in marginal habitats in Croatia. Glas Šum Pokuse pos. izd. 2006; 5:261-75.

[11] Kajba D, Bogdan S, Katičić I. Selection of clones of willow for biomass production in short rotations. Renewable Energy in the Republic of Croatia, HGK, Osijek, 27.-29.05.2007. p. 107-13.

[12] Kajba D, Domac J, Šegon V. Estimation of short rotation crops potential in the Republic of Croatia: illustration case within FP7 project Biomass Energy Europe. Sumarski List 01/2011;CXXXV(7-8):361-70.

[13] Glithero NJ, Wilson P, Ramsden SJ. Prospects for arable farm uptake of Short Rotation Coppice willow and miscanthus in England. Appl Energy 2013;107:209-18.

[14] Faasch RJ, Patenaude G. The economics of short rotation coppice in Germany. Biomass Bioenergy 2012:45:27-40.

[15] Borsukiewicz-Gozdur A, Wisniewski S, Mocarski S, Bankowski M. ORC power plant for electricity production from forest and agriculture biomass. Energy Convers Manage 2014;87:1180-5.
[16] Kilkis S. Energy system analysis of a pilot net-zero exergy district. Energy Convers Manage 2014;87:1077-92.

[17] Krajačić G, Duić N, Tsikalakis A, Zoulias M, Caralis G, Panteri E, et al. Feed-in tariffs for promotion of energy storage technologies. Energy Policy 2011:39:1410-25.

[18] Wang M, Wang J, Zhao P, Dai Y. Multi-objective optimization of a combined cooling, heating and power system driven by solar energy. Energy Convers Manage 2015;89:289-97.

[19] Raine RD, Sharifi VN, Swithenbank J. Optimisation of combined heat and power production for buildings using heat storage. Energy Convers Manage 2014;87:164-74.

[20] Mikulandrić R, Krajačić G, Duić N, Khavin G, Lund H, VadMathiesen B, et al. Performance analysis of a hybrid district heating system: a case study of a small town in Croatia. J Sustain Dev Energy Water Environ Syst 2015;3 (3):282-302. http://dx.doi.org/10.13044/i.sdewes.2015.03.0022.

[21] Pantaleo AM, Giarola S, Bauen A, Shah N. Integration of biomass into urban energy systems for heat and power. Part I: An MILP based spatial optimization methodology. Energy Convers Manage 2014;83:347-61.

[22] Pantaleo AM, Giarola S, Bauen A, Shah N. Integration of biomass into urban energy systems for heat and power. Part II: Sensitivity assessment of main techno-economic factors. Energy Convers Manage 2014;83:362-76.

[23] Rudra S, Rosendahl L, Blarke MB. Process analysis of a biomass-based quadgeneration plant for combined power, heat, cooling, and synthetic natural gas production. Energy Convers Manage 2015;106:1276-85.

[24] Dominkovic DF, Bacekovic I, Cosic B, Krajacic G, Puksec T, Duic N, et al. Zero carbon energy system of South East Europe in 2050. Appl Energy 2016. http:/ dx.doi.org/10.1016/j.apenergy.2016.03.046.

[25] Pfeifer Antun. Analysis of biomass production from short rotation crops on unused agricultural land for use in biomass power plants in Croatia. Diploma thesis (Bologna). University of Zagreb. Faculty of Mechanical Engineering and Naval Architecture. Mentor: Duić (Neven); 2015.

[26] Manual on fuels from wooden biomass. North-west Croatia Regional Energy Agency; 2008.

[27] Ćosić B, Stanić Z, Duić N. Geographic distribution of economic potential of agricultural and forest biomass residual for energy use: case study of Croatia. Energy 2011;36:2017-28.

[28] Sinnott RW. Virtues of the haversine. Sky Telesc 1984;68(2):159.

[29] Bilandzija N, Voca N, Kricka T, Matin A, Jurisic V. Energy potential of fruit tree pruned biomass in Croatia. Spanish J Agric Res 2012;10(2):292-8.

[30] Energy from field energy crops - a handbook for energy producers. Jyväskylä Innovation Oy \& MTT Agrifood Research Finland; 2009.

[31] Statistical yearbook - Croatian National Bureau of Statistics; 2004.

[32] Croatian agency for agricultural land - data set; 2014.

[33] Statistical yearbook - Croatian National Bureau of Statistics; 2014.

[34] The Act on renewable energy sources and high-efficient cogeneration. Republic of Croatia: Zagreb; 2015.

[35] Dominković DF Ćosić B, Bačelić Medić Z, Duić N. A hybrid optimization model of biomass trigeneration system combined with pit thermal energy storage. Energy Convers Manage 2015;104:90-9.

[36] Tariffs of the HEP ODS <http://www.hep.hr/ods/kupci/kucanstvo.aspx>.

[37] Energistyrelsen. Technology data for energy plants; May 2012.

[38] Hurtig J. Report-evaluation of a small scale district heating system in Ullared, Sweden; June 2010.

[39] Bruno JC, Lopez J, Ortiga J, Coronas A. Techo-economic design study of a large scale solar cooling plant integrated in a district heating and cooling network. In: 61st ATI National Congress - International Session "Solar Heating and Cooling". 